\title{
Physical linkage and transcriptional orientation of the tdc operon on the Escherichia coli chromosome**
}

\author{
Herbert P. Schweizer* and Prasanta Datta \\ Department of Biological Chemistry, University of Michigan, Ann Arbor, MI 48109-0606, USA
}

Received November 29, 1990/March 20, 1991

\begin{abstract}
Summary. The physical and genetic structure of 37 kilobases of DNA encopassing the $t d c$ region at $68.3 \mathrm{~min}$ of the Escherichia coli chromosome was determined by DNA sequence analysis and restriction mapping. Reexamination of new data concerning the direction of transcription of the $t d c$ operon revealed that in strain W3110 the $t d c$ region is located on a transposable segment of DNA.
\end{abstract}

Key words: Escherichia coli $-t d c$ operon - Mapping - Restriction analysis - Transposable element

The anaerobically-induced $t d c$ operon of Escherichia coli (Goss and Datta 1985; Goss et al. 1988) consists of three genes, $t d c A, t d c B$ and $t d c C$, encoding, respectively, a regulatory protein involved in inducer synthesis (S.R. Sadda and P. Datta, unpublished data), the biodegradative threonine dehydratase (EC 4.2.1.16) (Datta et al. 1987) and a threonine-serine permease (Sumantran et al. 1990). The operon was previously mapped at $68 \mathrm{~min}$ on the $E$. coli $\mathrm{K}-12$ chromosome and, by using a $t d c B$ lac $Z$ fusion, the direction of transcription was determined to be clockwise (Schweizer and Datta 1988). A recent genetic analysis indicated that a separate regulatory gene, $t d c R$, located immediately upstream of the $t d c$ operon in opposite transcriptional orientation, is needed for efficient expression of $t d c$ (Schweizer and Datta 1989 a). These four genes are found within a $6295 \mathrm{bp}$ $E c o$ RI fragment. Complete nucleotide sequence of the cloned DNA (Schweizer and Datta 1989b) revealed three additional open reading frames.(ORFs), flanking $t d c A B C$ and $t d c R$, which remain uncharacterized.

\footnotetext{
* Present address: Department of Microbiology and Infectious Diseases, University of Calgary, Calgary, Alberta, Canada, T2N 4N1

Offprint requests to: $\mathrm{P}$. Datta

** A portion of the data has appeared in a summary statement in J. Bacteriol. 172:2825:1990
}

To establish the physical linkage of the 6.3 kilobase pairs $(\mathrm{kb})$ fragment to adjacent regions of the $E$. coli chromosome, we compared the restriction patterns of $t d c$ DNA with those of lambda clones 514, 515 and 516 derived from coordinates $3320 \mathrm{~kb}$ to $3350 \mathrm{~kb}$ on the chromosome of strain W3110 (Kohara et al. 1987). The results presented in Fig. 1 show that the $6.3 \mathrm{~kb} E c o$ RI fragment was located in its entirety within the lambda clone 515 and in part on lambda clones 514 and 516. Restriction patterns of the latter lambda clones determined using BamHI, EcoRI and HindIII confirmed the identity of the regions flanking the $6.3 \mathrm{~kb}$ segment with

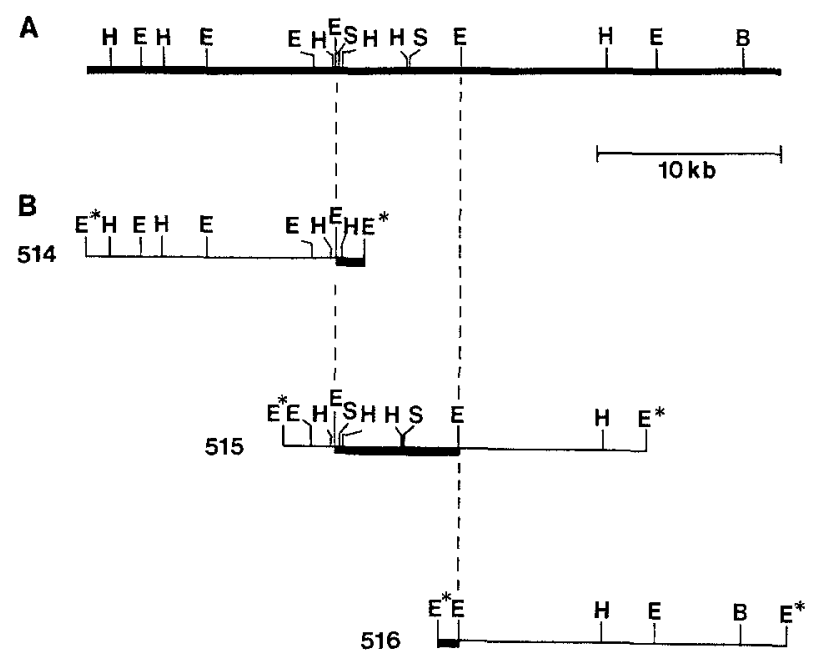

Fig. 1 A, B. Restriction map of the $t d c$ region (A) and extent of DNA carried by individual lambda phages from the region. Lysates of lambda clones 514,515 and 516 were prepared as described by Silhavy et al. (1984) using LE392 as the host. Phage DNA was prepared from $50 \mathrm{ml}$ lysates as described by Kaslow (1986). Phage DNA was digested with BamHI (B), EcoRI (E), HindIII (H) and SalI (S). Restriction fragments were separated on $0.8 \%$ agarose gels. Only phage 515 DNA was analyzed with Sall. E* indicates EcoRI sites from the polylinker region of EMBL4 (Frischauf et al. 1983). The extent of DNA of the $6.3 \mathrm{~kb} E c o$ RI fragment containing $t d c$ carried by the individual phages is indicated by the bold-faced line 


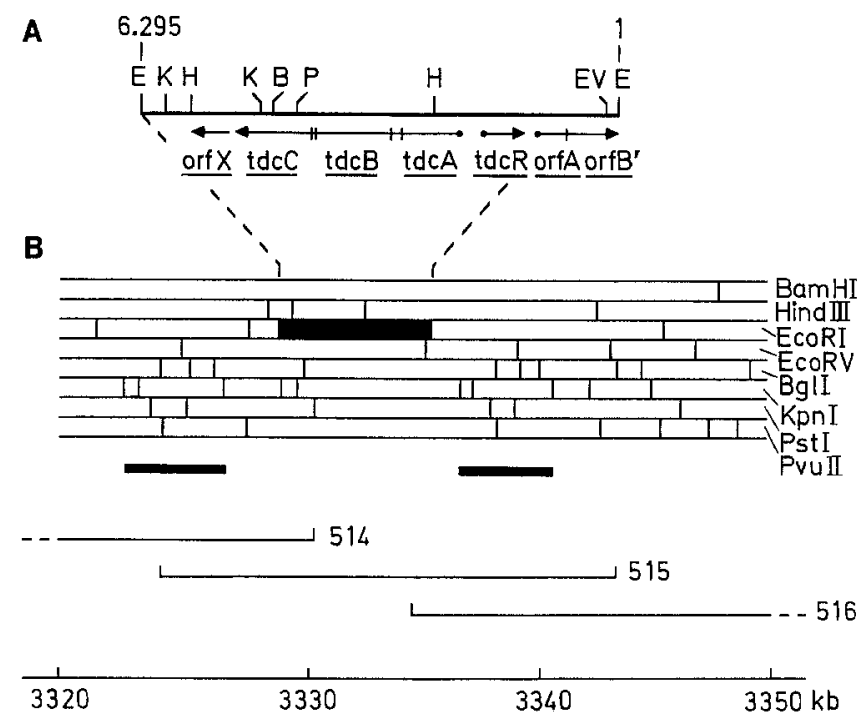

Fig. 2 A, B. Localization of the $t d c$ genes on the $E$. coli physical map. A restriction map of a $6295 \mathrm{bp} E c o$ RI restriction fragment harboring the $t d c$ genes and adjacent reading frames $(\mathbf{A})$. Location of restriction sites is based on DNA sequence analysis and was verified by restriction mapping. The gene products of all open reading frames have been identified in a minicell system (Goss and Datta (1985), Goss et al. (1988), Schweizer and Datta (1989a)). Abbreviations: B, BgII; E, EcoRI; EV, EcoRV; H, HindIII; K, $K p n I$. An $E$. coli restriction map of the $t d c$-containing region (B) based on a revised version (Y. Kohara, personal communication) of the published map (Kohara et al. 1987). Horizontal lines below the map indicate the extent of the chromosomal fragments carried by transducing phages designated on the right side of each fragment (see Fig. 1). The location of the $6.3 \mathrm{~kb}$ EcoRI fragment harboring $t d c$ is indicated in black. The extent of a $4 \mathrm{~kb}$ repeated region is indicated by solid bars

the published physical map of $E$. coli W3110 DNA (Kohara et al. 1987). The $6.3 \mathrm{~kb} E c o$ RI fragment harboring the $t d c$ operon maps approximately at coordinate $3330 \mathrm{~kb}$, or at $68.3 \mathrm{~min}$, on the $E$. coli chromosome. This result is in excellent agreement with the previously reported map position of 68 min established by genetic experiments (Goss and Datta 1984; Schweizer and Datta 1988).

Alignment of the $6.3 \mathrm{~kb} t d c$ DNA on the physical map, based on the restriction patterns indicated above, however, yielded a surprising finding: counterclockwise transcription of the $t d c A B C$ operon and $\operatorname{orf} X$, and clockwise transcription of $t d c R$ and orf $A$ and orf $B^{\prime}$ (Fig. 2). This is in obvious contrast to the clockwise direction of transcription of $t d c B$ established by Hfr-mediated chromosome transfer in strain MC4100 (Schweizer and Datta 1988), and the counterclockwise direction of transcription of $t d c R$ from DNA sequence data and deletion analysis (Schweizer and Datta 1989a), and from primer extension experiments to determine the transcription start site (HP Schweizer and P Datta, unpublished data). In view of this, we re-examined the direction of transcription of the $t d c B$ gene fused to $l a c Z$ by the procedure of Eckhardt (1977). A lysogen of MC4100 was isolated that had a $t d c B-l a c Z$ fusion, carried by $\lambda \mathrm{pSH} 202$, integrated in the $t d c$ region (TH9) (Schweizer and Datta 1988). Two possible orientations of the prophage and the fusion on the chromosome are shown in Fig. 3. Depending on the direction of transcription of the $t d c B$ gene, the lysogenization would place the $t d c B-l a c Z$ fusion on either side of $t d c$. To distinguish between the two possible arrangements the order of the markers $t d c$, tdc-lac and zgi-1:: Tn 10 was determined by P1 transduction. In order to obtain a suitable recipient, a $t d c A$ mutation was introduced into TH9 by transduction with P1 grown on TG426 ( $t d c A:: \operatorname{Tn} 5$ ) with selection of kanamycin resistance. (For a list of bacterial strains and phages, see Table 1). LacY was introduced into the resulting strain TH19 by transduction with P1 grown on NK5587 (lacY::Tn9) and selection for chloramphenicol resistance. The zgi-1::Tn10 insertion was introduced into TH9 by transduction with P1 grown on TH1 and selection for tetracycline resistance. Since the crosses involved a prophage in both donor and recipient, care was taken to ensure lambda lysogeny in each step of strain construction. The result of the three-factor crosses is shown
A

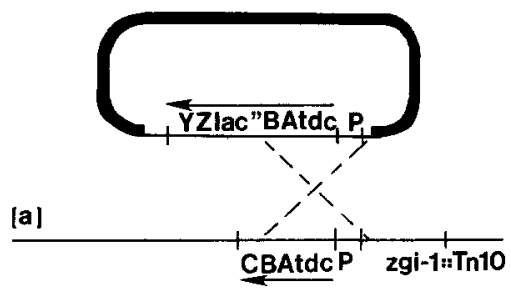

|b|

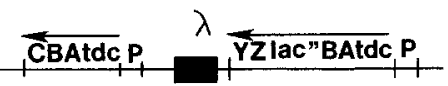

B
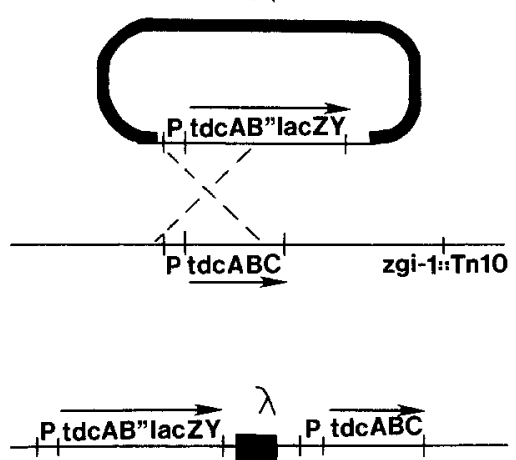

[c]

tdc lacr $\frac{1}{1}+\frac{1}{1}$

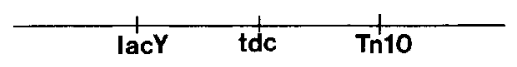

Fig. 3A, B. Integration of a $\lambda$ phage carrying a $t d c$-lac fusion into the $t d c$ region. Depending on the direction of transcription of $t d c$ two possibilities (A and B) arise. (a) Orientation of $t d c$ on the chromosome; (b) integration of $\lambda \mathrm{p}(t d c B$-lacZ $)$; (c) orientation of markers in $\mathrm{P} 1$ cross 
Table 1. Escherichia coli $\mathrm{K}-12$ strains and phages

\begin{tabular}{|c|c|c|}
\hline & Relevant genotype & Source or reference \\
\hline \multicolumn{3}{|l|}{ Strains } \\
\hline TH1 & Hfr metB1 relA1 zgi-1::Tn 10 & $\begin{array}{l}\text { Schweizer and Datta } \\
\text { (1988) }\end{array}$ \\
\hline TH9 & 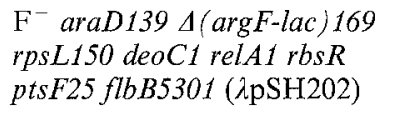 & $\begin{array}{l}\text { Schweizer and Datta } \\
\text { (1988) }\end{array}$ \\
\hline TH19 & TH9 tdc $A:: \operatorname{Tn} 5$ & This study \\
\hline TH20 & TH19 lac $Y:$ Tn 9 & This study \\
\hline TH21 & TH9 zgi-1::Tn 10 & This study \\
\hline LE392 & $\begin{array}{l}\mathrm{F}^{-} \text {hsdR514 supE } 44 \text { supF58 } \\
\Delta(\text { lacIZY)6 galK2 galT } 22 \\
\text { metB1 trp R55 }\end{array}$ & Maniatis et al. (1982) \\
\hline NK5587 & 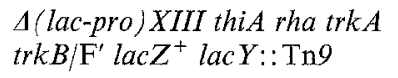 & N. Kleckner \\
\hline TG426 & $\mathrm{F}^{-}$thy $A$ thi $t d c A:: \operatorname{Tn} 5$ & Goss and Datta (1984) \\
\hline \multicolumn{3}{|l|}{ Phages } \\
\hline$\lambda \mathrm{pSH} 202$ & $\lambda(t d c B-l a c Z)$ hyb $b l a^{+}$ & $\begin{array}{l}\text { Schweizer and Datta } \\
(1988)\end{array}$ \\
\hline$\lambda 514$ & $\begin{array}{l}\text { גEMBL4 } 16.0 \mathrm{~kb} \text { Sau3A } \\
\text { partial } E \text {. coli fragment }\end{array}$ & Kohara et al. (1987) \\
\hline$\lambda 515$ & $\begin{array}{l}\lambda \text { EMBL4 } 19.5 \mathrm{~kb} \text { Sau } 3 \mathrm{~A} \\
\text { partial E. coli fragment }\end{array}$ & Kohara et al. (1987) \\
\hline$\lambda 516$ & $\begin{array}{l}\text { גEMBL4 } 18.7 \mathrm{~kb} \text { Sau3A } \\
\text { partial } E \text {. coli fragment }\end{array}$ & Kohara et al. (1987) \\
\hline
\end{tabular}

Table 2. Transductional analysis of the position of the $t d c B-l a c Z$ fusion with respect to $t d c$ and $z g i-1:: \operatorname{Tn} 10$

\begin{tabular}{llll}
\hline \multicolumn{2}{l}{ Strains (relevant genotype) } & $\begin{array}{l}\text { Recombinant } \\
\text { class }\end{array}$ & Percentage of total \\
\cline { 1 - 2 } Donor & Recipient & & \\
\hline $\mathrm{TH} 20$ & $\mathrm{TH} 21$ & $\mathrm{Lac}^{+} \mathrm{Tdc}^{+}$ & $0(0 / 194)$ \\
$\left(t d c^{+} l a c Y^{+}\right.$ & $(t d c A:: \operatorname{Tn} 5$ & $\mathrm{Lac}^{+} \mathrm{Tdc}^{-}$ & $0(0 / 194)$ \\
$z g i-1:: \operatorname{Tn} 10)$ & lac $Y:: \operatorname{Tn} 9)$ & $\mathrm{Lac}^{-} \mathrm{Tdc}^{-}$ & $88.7(172 / 194)$ \\
& & $\mathrm{Lac}^{-} \mathrm{Tdc}^{+}$ & $11.3(22 / 194)$ \\
\hline
\end{tabular}

A P1 lysate grown on TH20 was used to transduce TH21 to tetracycline resistance $\left(\mathrm{Tc}^{r}\right)$ according to Silhavy et al. (1984). Transductants were selected on LB medium containing $20 \mathrm{mM}$ sodium-citrate and $5 \mu \mathrm{g} / \mathrm{ml}$ tetracycline. Tdc was scored as kanamycin resistance $\left(\mathrm{Tdc}^{-}\right)$or sensitivity $\left(\mathrm{Tdc}^{+}\right)$on $\mathrm{LB}$ medium containing $20 \mathrm{mM}$ sodium citrate and $50 \mu \mathrm{g} / \mathrm{ml}$ kanamycin. Lac was scored as growth $\left(\mathrm{Lac}^{+}\right)$or no growth $\left(\mathrm{Lac}^{-}\right)$on M9 medium (Miller 1972) containing $0.2 \%$ lactose, $20 \mathrm{mM}$ sodium citrate and $5 \mu \mathrm{g} / \mathrm{ml}$ tetracycline

in Table 2. Selection was for tetracycline-resistance $\left(\mathrm{Tc}^{\mathrm{r}}\right)$. As can be seen, the $\mathrm{Tdc}^{+}$phenotype cotransduces with $\mathrm{Tc}^{\mathrm{r}}$ at a frequency of $11 \%$ whereas no co-transduction of $\mathrm{Lac}^{+}$and $\mathrm{Tc}^{\mathrm{r}}$ is observed. $t d c$ and $z g i-1:: \mathrm{Tn} 10$ normally co-transduce at a frequency of 8-18\% (Schweizer and Datta 1988). Thus, the deduced gene order is $t d c A B^{\prime \prime} l a c Z Y$-tdc-zgi-1::Tn10, indicating the direction of transcription of $t d c B-\operatorname{lac} Z$ towards $z g i-1:: \operatorname{Tn} 10$ or clockwise on the $E$. coli chromosome, according to the established linkage of $t d c$ to $z g i-1:: \operatorname{Tn} 10$ (Schweizer and
Datta 1988). Clearly, this finding corroborates the previously established direction of transcription using the same lac $Z$ fusion (Schweizer and Datta 1988) but is not consistent with the physical map of $E$. coli shown in Fig. 2.

How do we reconcile the apparent discrepancy in the transcriptional orientation of the $t d c$ genes between strains MC4100 and W3110? A plausible explanation is that this segment of the chromosome in certain $E$. coli strains may be a likely target site for transposon elements resulting in chromosomal rearrangements through translocation, duplication and inversion-like events. Indeed in strain W3110, Muramatsu et al. (1988) found at least four copies of IS5-related sequences at coordinates $3144 \mathrm{~kb}, 3158 \mathrm{~kb}, 3172 \mathrm{~kb}$, and $3186 \mathrm{~kb}$, and a separate one at coordinate $3328 \mathrm{~kb}$, each with a $14 \mathrm{~kb}$ flanking sequence exhibiting essentially identical restriction patterns. In addition, there appear to be two $4 \mathrm{~kb}$ regions, flanking the $6.3 \mathrm{~kb} E c o \mathrm{RI}$ fragment located at coordinate $3330 \mathrm{~kb}$, which are completely homologous with each other (Fig. 2B; Y. Kohara, personal communication). The authors (Muramatsu et al. 1988) proposed that the $14 \mathrm{~kb}$ DNA segments with IS5-related sequences may represent transposable elements and, over time, may have caused translocation and duplication of this region of the W3110 chromosome. Interestingly, these events appear to be specific for the particular W3110 strain used by this group of investigators (Kohara et al. 1987; Muramatsu et al. 1988) since the original $E$. coli $\mathrm{K}-12$ strain does not have a translocation at the $3160 \mathrm{~kb}$ region (Y. Kohara, personal communication). This notion is also consistent with the results reported from our laboratory (Goss and Datta 1984; Schweizer and Datta 1988) that a $\operatorname{Tn} 5$ insertion isolated in a W3110 strain, and plasmid-borne mutations introduced by allelic exchange into strain MC4100 always mapped to a single location at $68 \mathrm{~min}$. Thus, it is most likely that the observed orientation of the $t d c$ DNA on the physical map of the W3110 strain of Kohara et al. (1987), shown in Fig. 2, is fortuitous, and that the clockwise direction of transcription of $t d C A B C$ reported here and in a previous study (Schweizer and Datta 1988) reflects the correct orientation of the $t d c$ region on the E. coli chromosome.

Acknowledgements. We are grateful to Y. Kohara for unpublished information and for pointing out the duplication and transposition of $t d c$ in W3110. We acknowledge the gift of lambda clones from Y. Kohara via F.C. Neidhardt. This work was supported by Public Health Service Grant GM21436 from the National Institutes of Health.

\section{References}

Datta P, Goss TJ, Omnaas JR, Patil RV (1987) Covalent structure of biodegradative threonine dehydratase of Escherichia coli: homology with other dehydratases. Proc Natl Acad Sci USA 84:393-397

Eckhardt T (1977) Use of $\arg A$-lac fusions to generate lambda $\arg A$-lac phages and to determine the direction of $\arg A$ transcription in Escherichia coli. J Bacteriol 132:60-66

Frischauf AM, Lehrach H, Proustka A, Murray N (1983) Lambda 
replacement vectors carrying polylinker sequences. J Mol Biol $170: 827-842$

Goss TJ, Datta P (1984) Escherichia coli K-12 mutation that inactivates biodegradative threonine dehydratase by transposon $\mathrm{Tn} 5$ insertion. J Bacteriol 158:826-831

Goss TJ, Datta P (1985) Molecular cloning and expression of the biodegradative threonine dehydratase gene $(t d c)$ of Escherichia coli $\mathrm{K}-12$. Mol Gen Genet $201: 308-314$

Goss TJ, Schweizer HP, Datta P (1988) Molecular characterization of the $t d c$ operon of Escherichia coli K-12. J Bacteriol 170:5352-5359

Kaslow DC (1986) A rapid biochemical method for purifying lambda DNA from phage lysates. Nucleic Acids Res 14:6767

Kohara Y, Akiyama K, Isono K (1987) The physical map of the whole $E$. coli chromosome: Application of a new strategy for rapid analysis and sorting of a large genomic library. Cell 50:496-508

Maniatis T, Fritsch EF, Sambrook J (1982) Molecular cloning: a laboratory manual. Cold Spring Harbor Laboratory, Cold Spring Harbor, New York
Miller JH (1972) Experiments in molecular genetics. Cold Spring Harbor Laboratory, Cold Spring Harbor, New York

Muramatsu S, Kato M, Kohara Y, Mizuno T (1988) Insertion sequence IS 5 contains a sharply curved DNA structure at its terminus. Mol Gen Genet 214:433-438

Schweizer HP, Datta P (1988) Genetic analysis of the $t d c A B C$ operon of Escherichia coli K-12. J Bacteriol 170:5360-5363

Schweizer HP, Datta P (1989a) Identification and DNA sequence of $t d c R$, a positive regulatory gene of the $t d c$ operon of Escherichia coli. Mol Gen Genet 218:516-522

Schweizer HP, Datta P (1989b) The complete nucleotide sequence of the $t d c$ region of Escherichia coli. Nucleic Acids Res 17:3994

Silhavy TJ, Berman ML, Enquist LW (1984) Experiments with gene fusions. Cold Spring Harbor Laboratory, Cold Spring Harbor, New York

Sumantran VN, Schweizer HP, Datta P (1990) A novel membraneassociated threonine permease encoded by the $t d c C$ gene of Escherichia coli. J Bacteriol 172:4288-4294

Communicated by W. Goebel 